\title{
The effect of electronic word of mouth communication and brand image on purchase intention: A case of consumer electronics in Haripur, Pakistan
}

\author{
Anees Kazmi ${ }^{a^{*}}$ and Qazi Shujaat Mehmood ${ }^{b}$
}

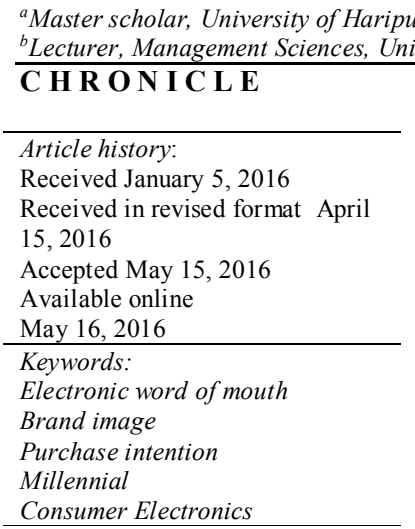

(C) 2016 Growing Science Ltd. All rights reserved.

\section{Introduction}

During the past few years, the world has been accepting new technologies and consumers have been switching towards the modern methods of living for making the lives easy and successful. In this regard, the companies have also established a new brand, made their products according to their customers' needs and demands and they have gone towards the customization, which helps them understand customers' needs and reach their satisfaction. The prospects of old times were not so conscious about the products because there was a lack of resources and the people were less aware of the products so they made decisions to buy certain products having certain features. Companies spent more on the product manufacturing and tried to make sure on the availability of their products on the market. They usually take benefit from product orientation and excluded the market orientation. The word of mouth (WOM) advertisement plays intensively a strong role in imposing a favorable influence towards the product judgments (Herr et al., 1991; Aydin \& Ozer, 2005). On the other hand, the services or the

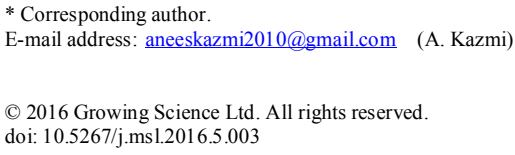


things which are seen directly called intangibles, are more risky to consumer because they can be evaluated based on WOM (Lewis \& Chambers, 2000; Litvin et al., 2008).

Sen and Lerman (2007) suggested that the reviews about the products by the customers on the internet help become more significant type of Online WOM communication that would definitely in the favor of those consumers who wish to collect information about a product before purchase and make purchase decision (Adjei et al., 2009; Zhu \& Zhang, 2010). Likewise, the branding of the product estimated as the basic wealth of the company and helps in the rise of the potential customer's trust in buying of any product or service, which would enable them to look better in understanding insubstantial elements that could not be touched. According to Yoo and Donthu (2001), the brand image can empower a company success, makes profit imminent, customer's enthusiasm to buy on higher prices, competing for an edge on competitive firms, and market readiness. According to Fishbein and Ajzen (1975), the buying behavior of the consumer can easily be judged by the buyer method, assessment and other apparatuses which result in the purchase intention. So the intention could predict about the buying will of the consumer towards any merchandise. It could be said that if the purchase intention is greater there will be more chance to buy the product (Dodds et al., 1991; Schiffman \& Kanuk, 2000). According to Dodds et al. (1991) when a buyer goes to market with the intention to purchase something that could benefit the buyers, it will come in the context of purchase intention. This behavior is enough for the marketers to estimate the buying decision of the customer. There are certain factors which may affect the change of buying behavior of the consumer so that it would make the marketer in serious difficulty to predict about the customer in different conditions.

The E-WOM communication is more effective and persuasive than other means of communications like advertising or print media (e.g. Bickart \& Schindler, 2001; Smith et al., 2005; Trusov et al., 2009). Sen and Lerman (2007) and Chatterjee (2001) suggest that WOM communication includes the ideas and thoughts of the customers about a product after or before using the product. Whereas the involvement of the internet makes it an online communication that is universal and less private, so called as electronic WOM communication (e.g. Davis \& Khazanchi, 2008; Chatterjee, 2001; Brown et al., 2007; Godes \& Mayzlin, 2004; Kiecker \& Cowles, 2001; Xia \& Bechwati, 2008). So consumer feelings got a new platform to share his/her ideas on this type of WOM communication (Bickart \& Schindler, 2001; Godes \& Mayzlin, 2004; Hennig-Thurau et al., 2004; Mayzlin, 2006) and it is assumed to be more effective and persuasive than that of offline WOM Communication due to its mass reach and greater availability (Chatterjee, 2001).

According to Sweeney (2006), millennial wish to learn by doing, and not dependent of the others, usually happy to participate in social interactions and learn from their mistakes could be called as trial and error. They want to be elastic in the matter of time and keep their promises and also expect from others to do the same in return. Millennial age group is conscious about their choices to wait for the last moment so that they could avail the best opportunity among the several option in any matters. Another major aspect of their age group is personalization and customer oriented because they do make preferences in their purchase of products services, once they have it, then they should want to mark changes in them to meet their growing needs and savors. As they are found to be sensitive in case of delays because they do not want to wait for a long time and want quick feedback. That trait makes them impatience towards the productivity, for this reason, their aspiration for rapidness and competence could not be challenged or overestimated (Sweeney, 2006). They are found to be more practical and enthusiastic in means of product or service orientations. This makes them more instant and more persuasive to acquire the right product at a right time and proud to be for their decisions otherwise switches to another category product.

For this reason, the current study is focusing on the millennial behavior and targeted them in the study because their quick responses towards any type of activity either related to the purchase of a product or serving any other for making them right decisions and helps them in what they want to accomplish. This study aims to evaluate the E-WOM communication effectiveness in the purchase decision and 
brand image of the millennial groups, regarding the purchase of consumer electronics .e. smartphones, digital cameras, laptops, iPods/Mp3 player, E-book reader, tablets and alike.

\section{Review of the Literature}

\section{$2.1 \quad$ E-Word of mouth communication}

According to Sweeney et al. (2008), WOM is used for a tool in promoting goods and services in the especially professional environment. Also suggested that confidence quality has a major impact on people preferences. Some factors which generally affect the positive WOM and may cause in impelling of the provided information. Yoon (2012) says that the people who are familiar with the actual wisdom of purchase point are more likely to be talked about the fact in society about those events. Also indicates that the social network is a crucial factor for acquiring and distributing E-WOM rationale. On the basis of five strategic experiential modules retailing ensure that E-WOM communication could be beneficial in different sort of purchase experiment which makes it functionally, and for enhancing E-WOM moreover suggest that the image and text exhibit more likeness in online shopping that will be a cause for disseminating E-WOM in both features of products and its occurrence. According to Lin (2011), EWOM in the creative living industry is based on three major places, farms parks and forest which have a positive response from customer viewpoint are experience, landscape, and trail respectively.

According to File et al. (1992), for sustaining the customer for a long period of time one should satisfy the need of existing customer which would help in decreasing the cost for attracting potential customers. That will surely benefit for showing loyalty towards the brand and the opponent struggle for marketing. That is why a pleased buyer will promote the significant word of mouth (WOM); helping other in suggesting them about the product which they have got pleasure and gratification. WOM is considered to be the fair mean of promotion and helps in reaping the huge benefit for the company. In consumer choices WOM plays important role, actually it is crucial part in consumer actions towards any brand or product, and found to be seven-time greater operative and meaningful to that of other source of media like newspaper and advertising (Bickart \& Schindler, 2001; Smith et al., 2005; Trusov et al., 2009) and in comparison with personal selling, WOM is four times more effective than radio advertisement in playing role to motivate customer to switch to another product. (Herr et al., 1991).

Day (1971) suggests that optimistic insolence, which could be made through WOM is considered to be nine times as actual as advertising which converts negative and neutral tendencies. In the ongoing age, the use of the internet is more often and the customer use to be safe with respect to the purchase of any product so for this they usually gather information relating to the product from the internet before purchase (Adjei et al., 2009; Zhu \& Zhang, 2010). Arndt (1967) talks about the WOM in new terminologies that could be their placement of WOM such as viral marketing and buzz marketing. Silverman (2001) suggests that every other kind of communication is taken to be as formal, even the advertisement, either in the newspaper or television because it is company oriented and paid for communication through an owned medium.

Word of mouth communication can take place by one to one or by any other type of sources like mail or telephone (Silverman, 2001). There are two types of endorsement: one is subjective and the other is objective that have to be kept into consideration while talking about the recommendations. Subjective could be the family member, mates, and colleges (Brown \& Reingen, 1987; Duhan et al., 1997) and the objective could be the experts opinions, journalist ideas, column writers in newspapers, publications. Online comments and discussions are lied in the objective part of endorsement because customer motivated through these type of activities regarding the purchase of a product or making choices. According to Lau and $\mathrm{Ng}$ (2001), it is the ancient tool to direct ideas and thoughts regarding the products and services brands. A flurry of the articles and books showing the interest of the about the WOM in a famous press recorded (Ozcan, 2004). File et al. (1992) define WOM as endorsement about the brands and the services to the people. 
According to Anderson (1998), positive WOM is linking to satisfying, bright, endorsement to others and unfluctuating obvious presentation. Borgida and Nisbett (1977) suggest that the WOM is likely to be greater than any other printed communication because WOM communication is more reliable. Because it flourishes in time and makes a lot of people to be communicated and effects positively,

Buttle (1998) says that researchers over 2400 years have been thinking about the WOM communication, but recently it has been evolved by the marketers relatively. Researchers and marketing specialist continuously search about the personal communication on customers buying intentions. In this way, the recent researches have been establishing on customer to customer prescriptive, but there is also an effect of WOM on employee and recruiting markets.

\subsection{Brand Image}

Martenson et al. (2007) suggest that branding image is the multi-dependent of the items regarding the product brand and equity of the product brands that will help in the branding of the corporate store image which would definitely lead to the loyalty of the customer's satisfaction.

In the past era the companies have invested their capitals in formulating brands because it helps in delivering the company reputation and its image to its target market which leads to the sale of service and relations. Aaker (1991) suggests brand equity as "a set of brand assets and liabilities linked to a brand, its name, and symbol that add to or subtract from the value provided by a product or service to a firm and/or to that firm's customers".

Keller (1993) talks about the CBBE and its scope, based on two things i.e. brand awareness and brand image, which means that the consumer tends to know about the brand and is performance and also about the image of the brand that how it makes someone different from others that is also the distinctive feature of brand to that of its competitors (Webster \& Keller, 2004).

The brand is composed of certain traits which describe its presence and differentiation and consumer meditates towards the brands and considers deriving benefits from its purchase, i.e. the value and the satisfaction in the mind of the consumer that makes him attracted to use a particular brand (Keller, 1993 1998).

According to Keller et al. (1993), the foreseeable, reliable and superior enactment in presenting a firm's product and services to the customer must be kept in mind because in services brands the very first experience is ascertained to decide about the use of the brand, by customers view point.

Consumers are conscious of using any product/brand because they are sensitive to the disturbances that could become in their way by means of any brand. So for the reason behind they usually depend on the certain brand which are trusted and fulfill their expectations and high-quality consistent (Cousins \& Menguc, 2006).

According to Aaker (1991), the pictorial information on the product or services may help to the possible success of the product irrespective of the product original feature and physical attribute. Marketers have to make a different brand image that could be possibly kept in the memories of the customer so that he could differentiate it with the competitor product and finally feels comfortable with the brand image towards self-esteem.

Arnold (1992) suggests that the brand having its position in the mind of customers that could be stable for a long time is very important in this time of competitive era (Belk et al., 1982).

Murphy (1990) suggests about the brand image as it is the most important attribute in the life cycle stage of the product. Additionally, consumer used to depend on the brand image when he is unaware of the product features and its tangible attributes because of the reason behind it is the busy market places and everyone rushes to have fill-up his/her desire as often as possible. Murphy (1990) also talks 
about the three stages of the product lifecycle, which starts from the entering of a new brand in the market called as "registration" stage in which the brand introduces itself by its inimitable characteristics. In this soundstage, it will have to compete the competitor product or brand and must adaptive to change for the market requirement and also to stay in the market and gain competitor edge. The third stage is the stage of image pronouncing that is, to build its own value and perception in the mind of the potential customer so that they could differentiate it from the competitor product.

Brand image projection to the customer has been the major activity in the marketing context, and also the vital part in the shopper performance research since 1980 (Dobni \& Zinkhan, 1990). Brand image has a different sense in the marketing from the beginning of its orientation. But the structure of the idea could not be formulated for its basic requirement (Dobni \& Zinkhan, 1990; Reynolds \& Gutman, 1984). Aaker (1991) suggested in his research paper that the brand image and brand identity are two different approaches to the brand, but these are taken from the network associated theory. Also, he explains that brand identity consists of certain inimitable features which are added by the brander from being desirous, (Aaker, 1991, p. 68) which means that brand is capable of what relations attached with the brand that it assures to the consumer. On the other hand, the brand image presents its perceptions in the mind of customers and what kind of placement is there in the mind of the customer (Aaker, 1996, p. 71).

\subsection{Purchase Intention}

Bennett (1975) says that the purchase intention towards any product will be dependent on the trust for the building attitude in using the brand. Also, he suggests that the buyer behavior theory helps in making affiliation to the trust in the brand and its buying. This will happen only in the case that the buyer is fully reliance on his/her ability to examine the traits of the brands.

Van der Heijden et al. (2003) say that the purchase intention of the consumer for online environment is dependent on two prescriptives; namely the trust and the technology-oriented perspective. Also, they suggest that if these two perspectives are strong enough with respect to customer shop online then they will definitely influence the purchase of the product online.

According to Daneshvary and Schwer (2000), buying mood could be in the association with the celebrity endorsers. So, for this reason, professional rodeo cowboys association's formulated for the brand advertisement in the USA.

Purchase intention is the necessary component in the buying behavior of the consumer because it influences the consumer to make choices among different alternatives present on the market on the basis of preferences and also helps in accommodating information regarding the particular purchase of the products or services. This is the reason behind the prediction of the buying behavior (Fishbein \& Ajzen, 1975). According to Dodds et al. (1991), the aim of the buyer will reflect his/her intention to purchase a product. According to Schiffman (2001) the greater the intention is, the greater will be the chance for the buyer to buy the product (Kanuk, 2000). Zeithaml (1988) and Dodds et al. (1991) suggest that the will of the buyer to decide for the product belongs to his/her knowledge and the environment from where the information is taken for the decision, including the alternative options.

\subsection{Hypotheses}

H1: E-WOM has a significant positive effect on purchase intention.

$\mathrm{H} 2$ : Brand image has a significant positive effect on purchase intention. 


\subsection{Theoretical Framework}

Fig. 1 demonstrates the structure of the proposed study.

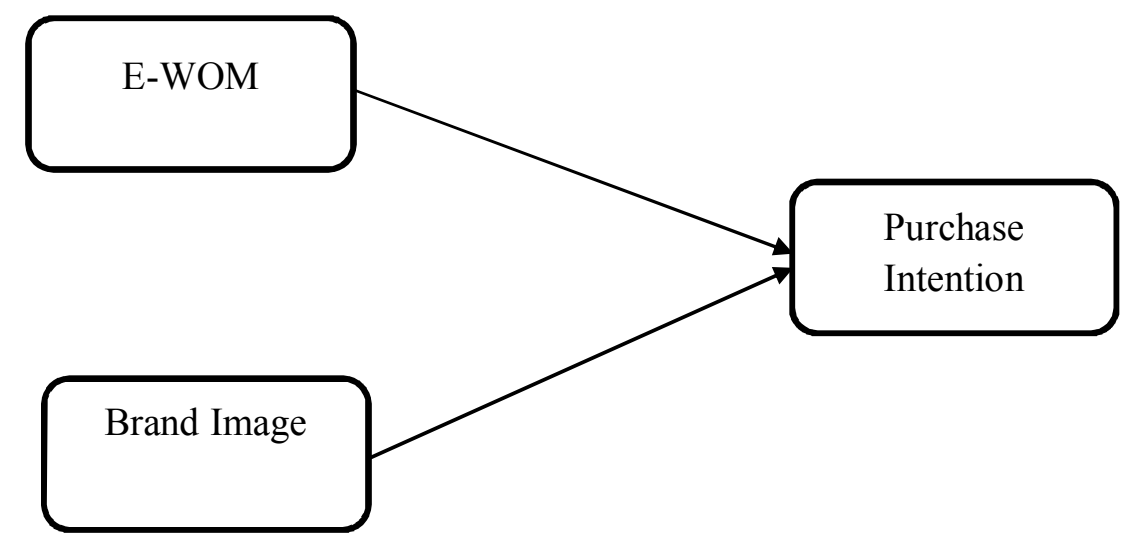

Fig. 1. The structure of the proposed study

\section{Research Methodology}

The research is conducted for the region of Haripur, so for this reason, the population targeted for sampling is the University of Haripur, and the students are the respondents for the proposed study. The simple convenient sampling with the non-probability method has been used for the collection of the data across different departments of the University. For the accomplishment of research objective, a self-administered questionnaire has been used for answering of the research literature and the questionnaire was pretested and revise. The study consists of four parts covers following issues.

1. Demographics

2. Electronic Word of Mouth communication

3. Brand image

4. Purchase intention

In the word of mouth section with six items, respondents were asked about using e-WOM communication adopted from Bambauer-Sachse and Mangold (2011). In $2^{\text {nd }}$ section, three items of the brand image were used to asked from the respondents about the brand image of the product related to the purchase of consumer electronics i.e. iPods, cell phone, cameras etc. taken from the previous study by Davis and Khazanchi (2008). In third section respondents were asked to respond about the purchase intention regarding the consumer electronics, in this section three items of questions were used to respond (Shukla, 2010). Electronic word of mouth, brand image and purchase intention were carried using 5 points Likert ranging from strongly disagree to strongly agree. The last section is to gather information about the respondent's i.e. age, gender and household income in the demographic section.

The total number of sample is 300, in which male respondents were 168 with the percentage of $56 \%$ while the female respondents were 132 with the percentage of $44 \%$. As the sample is drawn from the millennial group age ranges from (18 to 22 ) $65 \%$, (23 to 27 ) $26 \%$ and (28 to 34 ) $8 \%$. Income group ranges from under Rs. 25000 were $36.7 \%, 26000$ to 45000 were $16 \%, 46000$ t0 65000 were $17.3 \%$, 66000 to 85000 were $12 \%$ and above 85000 were $18 \%$. 


\section{Results}

\subsection{Correlation}

Table 1 presents the results of correlations between purchase intention (PI) and buying intention (BI).

Table 1

The results of correlations between PI and BI

\begin{tabular}{cccc}
\hline PI & 1.000 & $.355^{* *}$ & $.389^{* *}$ \\
BI & $.355^{* *}$ & 1.000 & $.307^{* *}$ \\
E-WOM & $.389^{* *}$ & $.307^{* *}$ & 1.000 \\
\hline ***Correlation is significant at the 0.01 level (2-tailed) & &
\end{tabular}

At the significance level of 0.01 all the variables are highly significant at $(0.00)$ in a two-tailed test. Pearson correlation for PI and $\mathrm{BI}$ is $0.355^{* *}$ which means the relationship is moderate. The correlation of E-WOM and Purchase intention is . $389^{* *}$ which means that the relationship is moderate.

\subsection{Regression Analysis}

Table 2 presents the results of regression analysis.

Table 2

The results of regression analysis

\begin{tabular}{lccc}
\hline & BETA & $\mathrm{t}$ & Significance \\
\hline \multicolumn{1}{c}{ E-WOM } & .310 & 5.72 & 0.000 \\
\multicolumn{1}{c}{ BI } & .260 & 4.80 & 0.000 \\
\hline a. $\quad \begin{array}{l}\text { Dependent variable PI } \\
\text { bredicator: (constant) BI, E-WOM }\end{array}$ & & & \\
$\mathrm{n}=300, \mathrm{R}$ square= $=0.21$, Adjusted $\mathrm{R}=.20$ & & & \\
$\mathrm{~F}=40.11$, significance 0.00 & & &
\end{tabular}

R-square measures the proportion of changes independent variable purchase intention that was explained the variation in the independent variables E-WOM and brand image in Table 2, the R-Square tells us $21.3 \%$ variation was explained while the $71.7 \%$ variation id due to other factors, which remained unexplained. The value of $F$ is 40.11 at the significance of 0.00 . The beta value for E-WOM is .310 and $t$ value is equal to 5.72 which is significant at 0.000 . Similarly, the beta Value for BI is .260 and t-value is 4.80 at significant of 0.000 .

\section{Discussion and Conclusion}

In the world of online communities, consumers are more linked with each other and have a high intention towards buying any expensive product. They can learn about the product and decide to purchase it or not depending on the arguments from other customers who are currently using that type of product. Moreover, the researchers and experiences may have suggested that in online communities, customers are likely interested in writing both positive and negative experiences derived from the use of the particular product. Therefore from the point of marketers the question is to find the effects of online WOM on the marketing prescriptive.

So for, the reason behind the current research is to examine the effect of e-WOM communication along with the brand image on the purchase intention of Consumer Electronic products. There are many prior studies on Electronic industry with respect to online WOM context but not in millennial age group. In addition, it has been shown that E-WOM has a direct effect on purchase intention. This point has been elaborated in prior studies (e.g. Chevalier \& Mayzlin, 2006), but not in the Consumer electronics 
industry. The results have many vital implications. The findings that the online WOM communication can cause purchase intention is specifically important for the consumer electronics manufacturers. Technology is the important key that can change the decision of the customer at the point of purchase, for example, the mobile internet may influence the decision by reading the online reviews about the product before purchase. In this case, the managers should recommend initiating the point of sale activities in the form of product trials with the objective of inspiring online WOM communication by enabling the customer to create their own impression about the product. Many studies have investigated the customer perception about service quality forecaster of consumer behavior intention such as WOM communication.

As an alternative, these companies should be known of the risk of negative WOM communication because the WOM is the strong tool to increase the reputation of the product or company as well as the decrease of the product sale even in the high equity branded product. Online WOM communication can help organizations even marketers monitor the growth of their brand by accessibility reach and transparency of the internet. Because the marketers may develop the tools for communicating with the consumer for making them loyal towards brand and increasing their knowledge about the product or brand by providing them valuable changes that previously lie in the mind of customer which reflect in the negative WOM communication could be easily neglected through better image about companies and brand using E.WOM.

WOM communication influences the consumer perception towards the brand and services which have high-quality belief. So it would be more effective to analyze the E-WOM communication and brand image in other product categories such as banking sector and financial institution.

Furthermore, the managers who are likely to strengthen the brand must test a construct linked within internet networks to explore the background of brand image for positive results.

\section{References}

Aaker, D.A. (1991). Managing Brand Equity: Capitalizing on the Value of a Brand Name. The Free Press, New York, NY.

Adjei, M. T., Noble, S. M., \& Noble, C. H. (2010). The influence of C2C communications in online brand communities on customer purchase behavior. Journal of the Academy of Marketing Science, 38(5), 634653.

Alfaro, L., Chanda, A., Kalemli-Ozcan, S., \& Sayek, S. (2004). FDI and economic growth: the role of local financial markets. Journal of international economics, 64(1), 89-112.

Arndt, J. (1967). Word of Mouth Advertising: A Review of the Literature. Advertising Research Foundation. Inc., New York, NY.

Arnold, R. D. (1992). The logic of congressional action. Yale University Press.

Aydin, S., \& Özer, G. (2005). The analysis of antecedents of customer loyalty in the Turkish mobile telecommunication market. European Journal of marketing, 39(7/8), 910-925.

Bambauer-Sachse, S., \& Mangold, S. (2011). Brand equity dilution through negative online word-of-mouth communication. Journal of Retailing and Consumer Services, 18(1), 38-45.

Belk, R. W., Bahn, K. D., \& Mayer, R. N. (1982). Developmental recognition of consumption symbolism. Journal of consumer research, 9(1), 4-17.

Bennett, P. D., \& Harrell, G. D. (1975). The role of confidence in understanding and predicting buyers' attitudes and purchase intentions.Journal of Consumer Research, 2(2), 110-117.

Bickart, B., \& Schindler, R. M. (2001). Internet forums as influential sources of consumer information. Journal of interactive marketing, 15(3), 31-40.

Borgida, E., \& Nisbett, R. E. (1977). The Differential Impact of Abstract vs. Concrete Information on Decisions1. Journal of Applied Social Psychology,7(3), 258-271.

Brown, J., Broderick, A. J., \& Lee, N. (2007). Word of mouth communication within online communities: Conceptualizing the online social network. Journal of interactive marketing, 21(3), 2-20. 
Buttle, F.A. (1998). Word of mouth: understanding and managing referral marketing. Journal of Strategic Marketing, 6, 241-254.

Chatterjee, P. (2001). Online reviews: do consumers use them?. Advances in Consumer Research, 28(1), 129-33.

Chevalier, J. A., \& Mayzlin, D. (2006). The effect of word of mouth on sales: Online book reviews. Journal of marketing research, 43(3), 345-354.

Cousins, P. D., \& Menguc, B. (2006). The implications of socialization and integration in supply chain management. Journal of operations management,24(5), 604-620.

Daneshvary, R., \& Schwer, R. K. (2000). The association endorsement and consumers' intention to purchase. Journal of consumer marketing, 17(3), 203-213.

Davis, A., \& Khazanchi, D. (2008). An empirical study of online word of mouth as a predictor for multiproduct category e-commerce sales.Electronic Markets, 18(2), 130-141.

Day, G. S. (1971). Attitude change, media and word of mouth. Journal of Advertising Research.

Dobni, D., \& Zinkhan, G. M. (1990). In search of brand image: A foundation analysis. Advances in consumer research, 17(1), 110-119.

Dodds, W. B., Monroe, K. B., \& Grewal, D. (1991). Effects of price, brand, and store information on buyers' product evaluations. Journal of Marketing Research, 28(3), 307-319.

Duhan, D. F., Johnson, S. D., Wilcox, J. B., \& Harrell, G. D. (1997). Influences on consumer use of wordof-mouth recommendation sources.Journal of the Academy of Marketing Science, 25(4), 283-295.

File, K. M., \& Prince, R. A. (1992). Positive word-of-mouth: customer satisfaction and buyer behavior. International Journal of Bank Marketing, 10(1), 25-29.

Fishbein, M., \& Ajzen, I. (1975). Belief, attitude, intention and behavior: An introduction to theory and research. Philosophy and Rhetoric, 10(2), 130-132.

Herr, P. M., Kardes, F. R., \& Kim, J. (1991). Effects of word-of-mouth and product-attribute information on persuasion: An accessibility-diagnosticity perspective. Journal of consumer research, 17(4), 454462.

Jensen, M. C., \& Murphy, K. J. (1990). Performance pay and top-management incentives. Journal of political economy, 98(2), 225-264.

Keller, K.L. (1993). Conceptualizing, measuring, and managing customer-based brand equity. Journal of Marketing, 57(1), 1-22.

Lau, G. T., \& Ng, S. (2001). Individual and situational factors influencing negative word-of-mouth behavior. Canadian Journal of Administrative Sciences/Revue Canadienne des Sciences de l'Administration, 18(3), 163-178.

Lewis, R.C., \& Chambers, R.E. (2000). Marketing Leadership in Hospitality, Foundations and Practices, Vol. III, Wiley, New York, NY.

Lin, S. J., Huang, L. M., Shih, M. L., \& You, H. J. (2011). Online word-of-mouth analysis of customer satisfaction with the cultural and creative industries in Taiwan-an example of creativity living industry. International Journal of Advancements in Computing Technology, 3(6), 242-251.

Martenson, R. (2007). Corporate brand image, satisfaction and store loyalty: A study of the store as a brand, store brands and manufacturer brands. International Journal of Retail \& Distribution Management, 35(7), 544-555.

Newman, J. W. (1957). Motivation research and marketing management.

Runyon, K. E., \& Stewart, D. W. (1987). Consumer behavior and the practice of marketing. Merrill Pub. Co.

Reynolds, T. J., \& Gutman, J. (1984). Advertising is image management. Journal of Advertising Research, 24(1), 27-37.

Sen, S., \& Lerman, D. (2007). Why are you telling me this? An examination into negative consumer reviews on the web. Journal of Interactive Marketing, 21(4), 76-94.

Sweeney, J. C., Soutar, G. N., \&Mazzarol, T. (2008). Factors influencing word of mouth effectiveness: receiver perspectives. European Journal of Marketing, 42(3/4), 344-364.

Sweeney, R. (2006). Millennial behaviors and demographics. Newark: New Jersey Institute of Technology, $12(3), 10$. 
Van der Heijden, H., Verhagen, T., \& Creemers, M. (2003). Understanding online purchase intentions: contributions from technology and trust perspectives. European Journal of Information Systems, 12(1), 41-48.

Webster, F.E., \& Keller, K.L. (2004). A roadmap for branding in industrial markets. Brand Management, $11(5), 388-402$.

Yoo, B., \& Donthu, N. (2001). Developing and validating a multidimensional consumer-based brand equity scale. Journal of Business Research, 52(1), 1-14.

Yoon, S. J. (2012). A social network approach to the influences of shopping experiences on ewom. Journal of Electronic Commerce Research, 13(3), 213-223.

Zhu, F., \& Zhang, X. (2010). Impact of online consumer reviews on sales: the moderating role of product and consumer characteristics. Journal of Marketing, 74(2), 133-48.

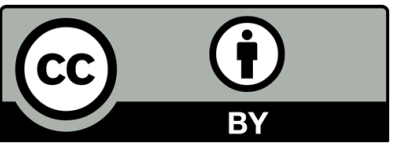

(C) 2016 by the authors; licensee Growing Science, Canada. This is an open access article distributed under the terms and conditions of the Creative Commons Attribution (CC-BY) license (http://creativecommons.org/licenses/by/4.0/). 